\title{
PERSEPSI GURU TERHADAP BUKU TEKS BAHASA INDONESIA KURIKULUM 2013 KELAS VII SMP NEGERI KOTA BENGKULU
}

\author{
Fatemah Dela Agusfina, Susetyo, dan Didi Yulistio \\ Program Studi Pendidikan Bahasa dan Sastra Indonesia \\ Jurusan Pendidikan Bahasa dan Seni \\ FKIP Universitas Bengkulu \\ Dela1718@yahoo.co.id
}

\begin{abstract}
Abstrak
Tujuan penelitian ini untuk mengetahui persepsi guru Bahasa Indonesia terhadap buku teks bahasa Indonesia Kurikulum 2013 kelas VII dalam aspek materi atau isi dan aspek penyajian. Penelitian ini menggunakan sampel purposif, yakni terhadap 9 orang guru Bahasa Indonesia kelas VII yang sudah tersertifikasi di SMPN 1, 3, 4, 11, dan 18 Kota Bengkulu. Teknik pengumpulan data menggunakan angket dan skala lima. Teknik analisis data yang digunakan penelitian ini adalah teknik deskriptif dan menghitung sederhana yang disajikan dalam bentuk tabel. Hasil penelitian menunjukan bahwa (1) persepsi guru terhadap buku teks Bahasa Indonesia Kurikulum 2013 kelas VII dalam aspek materi atau isi memperoleh nilai rata-rata 4,14 dengan kriteria sesuai, (2) persepsi guru terhadap buku teks Bahasa Indonesia Kurikulum 2013 kelas VII dalam aspek penyajian memperoleh nilai rata-rata 4,02 dengan kriteria sesuai.
\end{abstract}

Kata kunci: persepsi, guru, buku teks

\begin{abstract}
The purpose of this study is to determine the perceptions of Indonesian teachers on Indonesian textbooks of the curriculum of 2013 class VII in terms of material or content and presentation aspect. This study uses purposive samples, the sample of this study are 9 Indonesian VII class teachers who already have certification or professional teachers in SMPN 1, 3, 4, 11. and 18 Kota Bengkulu. Data collection techniques used in this research is a questionnaire. Data analysis technique used this research is descriptive technique and simple count presented in tabular form. The result of the research shows that (1) teacher's perception on Indonesian textbooks of grade VII curriculum in material or content aspect get average grade 4,14 with appropriate criteria, (2) teacher perception on Indonesian text book of 2013 curriculum of class VII in The presentation aspect earned an average rating of 4.02 with the corresponding criteria.
\end{abstract}

Keywords: perception, teachers, textbooks

\section{PENDAHULUAN}

Bahan ajar sangat penting keberadaannya bagi guru maupun siswa dalam proses pembelajaran. Tanpa bahan ajar akan sulit bagi guru untuk meningkatkan efektivitas pembelajaran. Demikian juga bagi siswa, tanpa bahan ajar akan sulit untuk menyesesuaikan diri dalam belajar selain mendapatkan penjelasan dari guru. Oleh karena itu, bahan ajar dianggap sebagai bahan yang dapat dimanfaatkan, baik oleh guru maupun siswa sebagai suatu upaya untuk memperbaiki mutu pembelajaran. 
Buku teks salah satu bahan ajar utama yang digunakan guru untuk membantu proses pembelajaran. Buku teks harus menarik dari segi isi, bahasa, dan lain-lain agar siswa yang membaca lebih bersemangat untuk mempelajarinya. Selain itu, isi buku teks juga harus berhubungan erat dengan pelajaranpelajaran lain agar dapat menambah ilmu pengetahuan.

Dalam proses pembelajaran, penggunaan buku teks dapat dipengaruhi oleh persepsi guru sebab guru dan siswa merupakan pengguna utama dan faktual. Persepsi guru terhadap buku teks yang telah digunakan bertujuan untuk dapat mengetahui sejauh mana kebutuhan guru dan siswa terhadap buku teks itu sendiri sehingga buku teks pelajaran yang digunakan dapat menjadi suatu sumber belajar yang efektif dalam memperoleh ilmu pengetahuan. Persepsi yang diberikan merupakan suatu proses pemahaman terhadap apa yang dialami.

$$
\text { Menurut Rakhmat (2011:50) }
$$

persepsi adalah pengalaman tentang objek, peristiwa, atau hubungan-hubungan yang diperoleh dengan menyimpulkan informasi dan menafsirkan pesan. Menurut Desmita (2014:118) persepsi adalah suatu proses penggunaan pengetahuan yang dimiliki untuk memperoleh dan menginterpretasi stimulus (rangsangan) yang diterima oleh sistem alat indera manusia. Menurut Walgito (2005:99) persepsi merupakan suatu proses yang didahului oleh proses penginderaan, yaitu merupakan proses diterimanya stimulus oleh individu melalui alat indera atau juga disebut proses sensoris. Karena itu proses persepsi tidak lepas dari proses penginderaan dan proses penginderaan merupakan proses pendahulu dari proses persepsi.

Selanjutnya, menurut Desmita (2014:118) persepsi adalah suatu proses penggunaan pengetahuan yang dimiliki untuk memperoleh dan menginterpretasi stimulus (rangsangan) yang diterima oleh sistem alat indera manusia. Menurut Shaleh dan Wahab (2004:88) persepsi didefinisikan sebagai proses yang menggabungkan dan mengorganisasikan data-data indera kita (penginderaan) untuk dikembangkan sedemikian rupa sehingga kita dapat menyadari di sekililing kita, termasuk sadar akan diri kita.

Jadi, persepsi guru dapat dikatakam sebagai suatu tanggapan terhadap suatu keyakinan yang ditangkap melalui penglihatan tentang isu-isu yang berkembang yang berkaitan dengan dunia pendidikan yang kemudian akan membentuk suatu konsep dalam menyatakan keiinginan yang kemudian akan terefleksi melalui sikap dan perilaku terhadap suatu objek tersebut.

Buku teks adalah buku pelajaran dalam bidang studi tertentu yang merupakan buku standar, yang disusun oleh para pakar dalam bidang itu buat maksud-maksud dan tujuan intruksional yang dilengkapi dengan sarana-sarana pengajaran yang serasi dan mudah dipahami oleh para pemakaianya di sekolah-sekolah dan perguruan tinggi sehingga dapat menunjang sesuatu program pengajaran (Tarigan dan Tarigan, 2009:13). Menurut Lange yang disitasi oleh Tarigan dan Tarigan (2009:12) buku teks adalah buku standar/buku setiap cabang khusus studi dan dapat terdiri atas dua tipe, yaitu buku pokok/utama dan suplemen/tambahan.

Beberapa persepsi dari guru mengenai buku teks Bahasa Indonesia Kurikulum 2013 di antaranya, ada yang menilai buku teks bahasa Indonesia kelas VII kurikulum 2013 terdapat kesulitan bagi siswa untuk memahami materi sehingga guru harus lebih detail menjelaskan materi tersebut, ada juga yang menilai buku teks bahasa Indonesia kelas VII kurikulum 2013 sudah lebih sesuai dan mudah dipahami setelah 
buku teks direvisi. Namun, penilaian atau persepsi ini perlu ditindaklanjuti untuk mengetahui kesesuaian buku teks dengan materi, penyajian yang sistematis, penggunaan bahasa, serta sesuai dengan kurikulum yang berlaku.

Penelitian ini bertujuan untuk mengetahui persepsi, pandangan, penilaian, dan tanggapan atau gambaran guru terhadap sebuah buku teks yaitu buku teks Bahasa Indonesia Kelas VII Kurikulum 2013 yang diterbitkan oleh Kementerian Pendidikan dan Kebudayaan Republik Indonesia tahun 2014.

Berdasarkan uraian di atas, maka penulis melakukan penelitian mengenai persepsi guru terhadap buku teks Bahasa Indonesia Kurikulum 2013 Kelas VII SMP Negeri Kota Bengkulu yang diterbitkan Kementerian Pendidikan dan Kebudayaan Republik Indonesia tahun 2014.

\section{METODE}

Metode yang digunakan dalam penelitian adalah metode deskriptif kuantitaif. Metode deskriptif dilakukan apabila peneliti ingin menjawab persoalanpersoalan tentang gejala-gejala yang ada atau berlaku pada masa sekarang (Susetyo, 2015:17). Selanjutnya metode ini bertujuan untuk membuat pencandraan atau deskripsi secara sistematis, faktual, dan akurat mnegenai situasi-situasi/ kejadian-kejadian, fakta-fakta, dan fenomena yang terjadi pada masa sekarang ketika penelitian sedang dilakanakan.

Populasi dalam penelitian ini adalah guru Bahasa Indonesia yang mengajar di kelas VII SMPN Kota Bengkulu yang menggunakan Kurikulum 2013. Sampel yang digunakan adalah sampel purposif. Sampel penelitian ini adalah guru bahasa Indonesia yang sudah sertifikasi atau guru yang profesional yang mengajar di SMPN 1 Kota Bengkulu, SMPN 3 Kota Bengkulu, SMPN 4 Kota Bengkulu, SMPN 11 Kota
Bengkulu dan SMPN 18 Kota Bengkulu yang sekolahnya menggunakan Kurikulum 2013 berjumlah 9 guru. Pada SMPN 2 Kota Bengkulu akan dijadikan untuk uji instrumen penelitian.

Teknik pengumpulan data dalam penelitian ini menggunakan teknik angket dan skala lima. Teknik Angket digunakan untuk mengetahui persepsi guru bahasa Indonesia terhadap buku teks Kurikulum 2013 kelas VII. Teknik angket caranya melalui pertanyaan-pertanyaan yang sengaja diajukan kepada individu/responden. Jawaban yang diberikan secara tertulis dan dijawab secara tertulis. Skala lima digunakan untuk persepsi seseorang atau sekelompok orang tentang fenomena sosial. Dengan skala lima, maka variabel yang akan diukur dijabarkan menjadi indikator variabel.

Penelitian ini menggunakan instrumen berupa angket. Angket yang digunakan termasuk angket tertutup yang jawabannya telah disediakan jawabannya sehingga responden tinggal memilih jawaban yang telah disediakan. Pada uji instrumen menggunakan uji coba validitas dan reliabilitas untuk melihat valid atau tidaknya instrumen tersebut.

Teknik analisis data menggunakan teknik deskriptif. Dengan cara data dikumpulkan dari subjek penelitian dengan membagi angket. Angket boleh dibawa pulang atau diisi di rumah dan diisi sesuai dengan petunjuk yang sudah diberikan. Setelah diisi angket dikembalikan kemudian direkam pada suatu tabel.

Hasil rata-rata kemudian diinterpretasikan hasilnya dengan ketentuan sebagai berikut.

Tabel 1. Interpretasi Hasil Data

\begin{tabular}{|l|c|}
\hline \multicolumn{1}{|c|}{ Rentang Rata-rata } & Kriteria \\
\hline $4,2-5,0$ & Sangat Sesuai \\
\hline $3,4-4,1$ & Sesuai \\
\hline $2,6-3,3$ & Cukup \\
\hline $1,8-2,5$ & Tidak Sesuai \\
\hline $1,0-1,7$ & $\begin{array}{c}\text { Sangat tidak } \\
\text { Sesuai }\end{array}$ \\
\hline
\end{tabular}




\section{HASIL DAN PEMBAHASAN}

\section{Hasil Penelitian}

\section{Persepsi Guru Terhadap Materi/isi}

Persepsi guru terhadap buku teks bahasa Indonesia kelas VII Kurikulum 2013 dalam aspek materi memperoleh hasil rata-rata 4,14 dengan kriteria sesuai. Penilaian presentase pada aspek materi atau isi meliputi indikator gambaran, dan tanggapan. Maka, gambaran dan tanggapan kesembilan guru tersebut terhadap materi atau isi yang terdapat di dalam buku teks sudah sesuai karena buku teks bahasa Indonesia kelas VII kurikulum 2013 telah memuat kompetensi inti (sikap keagamaan, sikap sosial, pengetahuan, dan penerapan pengetahuan), kemudian untuk cakupan materi dan keakuratan materi dalam buku teks bahasa buku teks bahasa Indonesia kelas VII sudah sangat sesuai dengan kurikulum 2013.

\section{Persepsi Guru Terhadap Penyajian}

Persepsi guru terhadap buku teks bahasa Indonesia Kurikulum 2013 kelas VII dalam aspek penyajian memperoleh hasil rata-rata 4,02 dengan kriteria sesuai. Penilaian presentase pada aspek materi atau isi meliputi indikator kesan, membandingkan, menginterpretasikan, dan penilaian. maka menurut kesembilan guru tersebut penyajian yang terdapat di dalam buku teks sesuai karena buku teks bahasa Indonesia kelas VII kurikulum 2013 telah memuat teknik penyajian, pendukung penyajian materi, penyajian pembelajaran, dan kelengakapan penyajian.

Buku teks bahasa Indonesia kelas VII Kurikulum 2013 menurut persepsi kesembilan guru buku teks bahasa Indonesia kelas VII Kurikulum 2013 memiliki sistematika penyajian, dan pada setiap akhir bab diberikan rangkuman dengan menggunakan kalimat ringkas dan jelas sehingga mempermudah siswa memahami materi setiap bab. Namum persepsi guru pada keruntutan penyajian materi masih belum berurutan mulai dari mudah ke sukar, dari konkret ke abstrak, dan lain-lain.

\section{PENUTUP \\ Kesimpulan}

Berdasarkan hasil penelitian dan pembahasan persepsi guru terhadap buku teks bahasa Indonesia Kurikulum 2013 kelas VII dapat diambil kesimpulan bahwa aspek materi dan aspek penyajian dari kesembilan guru bahasa Indonesia terhadap buku teks bahasa Indonesia kelas VII sudah sesuai dengan Kurikulum 2013 dan dapat digunakan siswa untuk belajar.

\section{Saran}

Saran bagi guru bahasa Indonesia, dalam memilih buku teks yang akan digunakan siswa hendaknya mengevaluasi buku teks terlebih dahulu agar sesuai untuk siswa dalam proses pembelajaran.

Saran bagi sekolah, hendaknya bekerja sama dengan guru mata pelajaran untuk menyeleksi dan menilai terlebih dahulu dalam penentuan penggunaan buku teks yang layak dalam pembelajaran.

\section{DAFTAR PUSTAKA}

Desmita. 2014. Psikologi Perkembangan Peserta Didik. Bandung: PT Remaja Rosdakarya.

Rakhmat, J. 2011. Psikologi Komunikasi. Bandung: PT Remaja Rosdakarya.

Shaleh, A. R. \& Muhbib A. W. 2004. Psikologi Suatu Pengantar (Dalam Perspektif Islam. Jakarta: Prenada Media.

Susetyo. 2015. Penelitian Kualitatif Dan Penelitian Tindakan Kelas. Bengkulu: Fakultas Keguaruan Dan Ilmu Pendidikan Universitas Bengkulu. 
Tarigan, H. G. \& Djago T. 2009. Telaah Buku Teks Bahasa Indonesia. Bandung: Angkasa.
Walgito, B. 2005. Pengantar Psikologi Umum. Yogyakarta: Andi. 